\title{
Efficacy and Safety of D-dimer, Weight, and Renal Function-Adjusted Thromboprophylaxis in Patients with Coronavirus Disease 2019 (COVID-19)
}

\author{
Deepa R. J. Arachchillage, MRCP, MD, FRCPath ${ }^{1,2,3}$ \\ Peter Kozman, $\mathrm{MBBS}^{4}$ Emma Mi, MA, MB, BChir ${ }^{4}$
}

Christine Shi, BA, BMBCh ${ }^{4}$

Noora Buti, $B$, 1

Elika

David Saliu, BSc, MBBS ${ }^{4}$

Tashef, MRCS, FRCR

Susan J. Copley, FRCP, FRCR, MD ${ }^{5}$ Carlos Gomez, FRCA, MD, EDICM, FRICM ${ }^{6}$ Richard Leonard, FRCA 6 Riaz Aziz, MRCP, FRCA ${ }^{7}$ Abdul A. Shlebak, MD, FRCP, FRCPath ${ }^{1, *}$ Mike Laffan, DM, FRCP, FRCPath ${ }^{1,2, *}$

Address for correspondence Deepa R.J. Arachchillage, MRCP, MD, FRCPath, Department of Haematology, Imperial College Healthcare NHS Trust and Imperial College London, Hammersmith Hospital, 4th Floor, Commonwealth Building, Du Cane Road, London W12 ONN, United Kingdom (e-mail: d.arachchillage@imperial.ac.uk).

prominent in the pulmonary circulation both ante- and postmortem. ${ }^{8}$ The prominence of large and small vessel thrombosis in the pathophysiology of COVID-19 and its high frequency despite standard or sometimes increased intensity LMWH suggests that intensified prophylaxis may be beneficial. However, any benefit from this approach would need to be balanced against a possible increase in bleeding complications. The use of intensified versus standard dose LMWH is being investigated in several clinical trials, although only recently initiated in the United Kingdom. Pending the results of such studies, individual National Health Service (NHS) Trusts have developed local thromboprophylaxis guidelines for COVID-19.

This retrospective study assesses the safety and efficacy of D-dimer-, weight-, and renal function-adjusted thromboprophylaxis in patients admitted to a major tertiary NHS Trust in London, U.K. We hypothesized that body mass, renal function, and D-dimer may be important determinants in patients with COVID-19 who may benefit from increased heparin dosage.

The study was undertaken as a service evaluation project, approved by Imperial College Healthcare NHS Trust Clinical Effectiveness Unit and consent was not required. - Table 1 summarizes the recommended thromboprophylaxis regimen.

(c) 2021. Thieme. All rights reserved. Thieme Medical Publishers, Inc., 333 Seventh Avenue, 18th Floor, New York, NY 10001, USA
DOI https://doi.org/ $10.1055 / \mathrm{s}-0040-1722309$. ISSN 0094-6176. and Preventing Thrombosis in COVID-19 -Part II; Guest Editors: Emmanuel J. Favaloro, PhD, FFSc (RCPA) and Giuseppe Lippi, MD. published online
January 22, 2021
Issue Theme Maintaining Hemostasis 
Table 1 Weight-, D-dimer-, and renal function-adjusted thromboprophylaxis for patients with COVID-19 admitted to hospitals as per local National Health Service

\begin{tabular}{|c|c|c|c|c|}
\hline D-dimer (ng/mL) FEU & Weight & $\begin{array}{l}\mathrm{LMWH} \\
\mathrm{CrCl}>30 \mathrm{~mL} / \mathrm{min}\end{array}$ & $\begin{array}{l}\text { LMWH } \\
\mathrm{CrCl} 20-30 \mathrm{~mL} / \mathrm{min}\end{array}$ & $\begin{array}{l}\mathrm{UFH} \\
\mathrm{CrCl}<20 \mathrm{~mL} / \mathrm{min}\end{array}$ \\
\hline \multirow[t]{4}{*}{$<1000$} & $<50 \mathrm{~kg}$ & Enoxaparin $20 \mathrm{mg}$ OD & Enoxaparin $20 \mathrm{mg}$ OD & 2,500 units $\mathrm{BD}$ \\
\hline & $50-100 \mathrm{~kg}$ & Enoxaparin $40 \mathrm{mg}$ OD & Enoxaparin $20 \mathrm{mg}$ OD & 5,000 units $\mathrm{BD}$ \\
\hline & $100-150 \mathrm{~kg}$ & Enoxaparin $40 \mathrm{mg}$ BD & Enoxaparin $40 \mathrm{mg}$ OD & 7,500 units $\mathrm{BD}$ \\
\hline & $>150 \mathrm{~kg}$ & Enoxaparin $60 \mathrm{mg}$ BD & Enoxaparin $40 \mathrm{mg}$ OD & 10,000 units BD \\
\hline \multirow[t]{4}{*}{$1,000-3,000$} & $<50 \mathrm{~kg}$ & Enoxaparin $40 \mathrm{mg}$ OD & Enoxaparin $20 \mathrm{mg}$ OD & 5,000 units $B D$ \\
\hline & $50-100 \mathrm{~kg}$ & Enoxaparin $40 \mathrm{mg}$ BD & Enoxaparin $40 \mathrm{mg}$ OD & 7,500 units $B D$ \\
\hline & $100-150 \mathrm{~kg}$ & Enoxaparin $80 \mathrm{mg}$ BD & Enoxaparin $40 \mathrm{mg}$ BD & 10,000 units $B D$ \\
\hline & $>150 \mathrm{~kg}$ & Enoxaparin $120 \mathrm{mg} \mathrm{BD}$ & Enoxaparin $60 \mathrm{mg}$ BD & 15,000 units $B D$ \\
\hline \multirow[t]{3}{*}{$>3000$} & $<35 \mathrm{~kg}$ & $\mathrm{D} / \mathrm{W}$ hem & $\mathrm{D} / \mathrm{W}$ hem & \multirow[t]{3}{*}{ D/W hem } \\
\hline & $35-160 \mathrm{~kg}$ & Tinzaparin 175 units/kg OD & $\begin{array}{l}\text { Tinzaparin } 175 \text { units/kg } \\
\text { OD }\end{array}$ & \\
\hline & $>160 \mathrm{~kg}$ & $\mathrm{D} / \mathrm{W}$ hem & $\mathrm{D} / \mathrm{W}$ hem & \\
\hline
\end{tabular}

Abbreviations: $\mathrm{BD}$, twice daily; $\mathrm{CrCl}$, creatinine clearance; $\mathrm{D} / \mathrm{W}$ hem, discuss with hematologist on call; $\mathrm{FEU}$, fibrinogen equivalent; LMWH, low molecular weight heparin; OD, once daily; UFH, unfractionated heparin.

Thromboprophylaxis as per guidelines was started on admission in all cases and the standard thromboprophylaxis was $40 \mathrm{mg}$ of enoxaparin except in patients with creatinine clearance $<30 \mathrm{~mL} / \mathrm{min}$, for whom it was $20 \mathrm{mg}$ of enoxaparin. Data were collected from the electronic records of consecutive patients admitted from April 10 to 23, 2020. Statistical analyses were performed using GraphPad Prism v8.4.2. Results are reported as mean and standard deviation (SD) or median (range) as appropriate. Comparisons for normally distributed or log-transformed data were done using the two-sample independent $t$-test, while Wilcoxon rank-sum test was used for non-normal data. Cox proportional hazards models were used to determine the said predictors first using univariate models and then where possible a multivariable model when the variables in the univariate model were significant at $p<0.05$. Fisher's exact test was used to compare differences between groups where appropriate. A two-sided $p<0.05$ was considered statistically significant.

Of the 261 patients admitted with suspected COVID-19 during the study period, this analysis is restricted to the 171 with COVID-19 confirmed by reverse transcription polymerase chain reaction from throat swabs and not on anticoagulant on admission. Mean age was $65(\mathrm{SD}=16.2)$ years and $59.6 \%$ were male. Out of 171 patients included in this study, 82 patients had computed tomography pulmonary angiography (CTPA), and of these, 21 patients had confirmed pulmonary embolism (PE) making an overall PE rate of 12.3\% (21/171) in the study population. Out of the 82 patients who had CTPA, 48 patients had the imaging based on clinical suspicion of PE of which 10/48 (20.8\%) had confirmed PE, and 34 patients had CTPA prompted by D-dimer levels $>3,000 \mathrm{ng} / \mathrm{mL}$ (normal range $<500 \mathrm{ng} / \mathrm{mL}$ fibrinogen equivalent) of which $34 / 82$ patient (32.3\%) had confirmed PE. Two patients had deep vein thrombosis (one with PE in the CTPA group) confirmed by Doppler scan, one patient had cerebral infarction confirmed by CT brain, and another had portal vein thrombosis confirmed by CT abdomen. Therefore, the overall venous thrombosis and arterial thrombosis rates were $13.4 \%(23 / 171)$ and $0.6 \%$ (1/171), respectively. - Table 2 compares first the characteristics of patients who did or did not develop thrombosis. There

Table 2 Comparison of demographic and clinical features and outcomes of patients with COVID-19 who develop thrombosis versus no thrombosis

\begin{tabular}{|c|c|c|c|c|}
\hline Variable & Category & $\begin{array}{l}\text { Thrombosis } \\
\text { Mean (\%) } \\
(24 / 171 ; \%)\end{array}$ & $\begin{array}{l}\text { No thrombosis } \\
\text { Mean }(\%) \\
(147 / 171 ; \%)\end{array}$ & $p$-Value \\
\hline Age (y) (mean [SD]) & & $67.3(14.7)$ & $65.0(18.0)$ & 0.66 \\
\hline \multirow[t]{2}{*}{ Gender } & Male & $16(66.6)$ & $86(58.5)$ & \\
\hline & Female & $8(33.4)$ & $61(41.5)$ & 0.50 \\
\hline Body mass index $\left(\mathrm{kg} / \mathrm{m}^{2}\right)$ (mean [SD]) & & $29.37(7.1)$ & $27.2(8.2)$ & 0.62 \\
\hline \multirow[t]{2}{*}{ Ethnicity } & Arab & $2(8.3)$ & $1(0.7)$ & \\
\hline & Asian/other Asian & $2(8.3)$ & $8(5.4)$ & \\
\hline
\end{tabular}


Table 2 (Continued)

\begin{tabular}{|c|c|c|c|c|}
\hline Variable & Category & $\begin{array}{l}\text { Thrombosis } \\
\text { Mean (\%) } \\
\text { (24/171; \%) }\end{array}$ & $\begin{array}{l}\text { No thrombosis } \\
\text { Mean (\%) } \\
\text { (147/171; \%) }\end{array}$ & $p$-Value \\
\hline & Black & $3(12.5)$ & 19 (12.9) & \\
\hline & Chinese & $0(0.0)$ & $2(1.4)$ & \\
\hline & Indian & $1(4.2)$ & $11(7.5)$ & \\
\hline & Mixed & $0(0.0)$ & $2(1.4)$ & \\
\hline & Other & $8(33.3)$ & $29(19.7)$ & \\
\hline & White & $8(33.3)$ & $71(48.3)$ & \\
\hline & Unknown & $0(0.0)$ & $4(2.7)$ & 0.37 \\
\hline \multirow[t]{4}{*}{ Smoking } & Current & $2(8.3)$ & $13(9.0)$ & \\
\hline & No & $15(65.4)$ & $72(49.7)$ & \\
\hline & Ex-smoker & $5(19.2)$ & $26(18.9)$ & \\
\hline & Unknown & $2(8.3)$ & $34(23.5)$ & 0.35 \\
\hline \multirow[t]{2}{*}{ Diabetes mellitus } & Yes & $6(25.0)$ & $49(33.3)$ & \\
\hline & No & $18(75.0)$ & $98(66.7)$ & 0.46 \\
\hline \multirow[t]{2}{*}{ Cardiac history } & Yes & $5(20.8)$ & $18(12.2)$ & \\
\hline & No & $19(79.2)$ & $129(87.8)$ & 0.32 \\
\hline \multirow{2}{*}{$\begin{array}{l}\text { Malignancy - Active or treated in } \\
\text { last } 6 \text { mo }\end{array}$} & Yes & $3(12.5)$ & $16(10.8)$ & \\
\hline & No & $21(87.5)$ & $131(89.2)$ & 0.67 \\
\hline \multirow[t]{2}{*}{ Autoimmune disease } & Yes & $3(12.5)$ & $11(7.4)$ & \\
\hline & No & $21(87.5)$ & $136(92.6)$ & 0.42 \\
\hline \multirow[t]{2}{*}{ Family history of VTE } & Yes & $4(16.7)$ & 17 (11.5) & \\
\hline & No & $20(83.3)$ & $130(88.5)$ & 0.50 \\
\hline \multirow[t]{2}{*}{ Presence of renal or hepatic dysfunction } & Yes & $4(16.7)$ & $6(4.0)$ & \\
\hline & No & $20(83.3)$ & $141(96.0)$ & 0.035 \\
\hline \multirow[t]{2}{*}{ Renal replacement therapy } & Yes & $4(16.7)$ & $6(4.1)$ & \\
\hline & No & $20(83.3)$ & $141(95.9)$ & 0.045 \\
\hline \multirow{2}{*}{$\begin{array}{l}\text { On admission correct dose of } \\
\text { enoxaparin was prescribed }\end{array}$} & Yes & $9(37.5)$ & $101(68.7)$ & \\
\hline & No & $15(62.5)$ & $46(31.3)$ & 0.005 \\
\hline \multirow[t]{2}{*}{ TEDS prescribed on admission } & Yes & $2(8.3)$ & $20(13.6)$ & \\
\hline & No & $22(91.7)$ & $127(86.4)$ & 0.74 \\
\hline \multirow[t]{2}{*}{ ITU admission } & Yes & $10(41.7)$ & $19(12.9)$ & \\
\hline & No & $14(58.3)$ & $128(87.1)$ & 0.001 \\
\hline \multirow[t]{2}{*}{ Major bleeding } & Yes & $2(8.3)$ & $9(6.1)$ & \\
\hline & No & $22(91.7)$ & $138(93.9)$ & 0.65 \\
\hline \multirow[t]{2}{*}{ Minor bleeding } & Yes & $4(16.7)$ & $17(11.6)$ & \\
\hline & No & $20(83.3)$ & $130(88.4)$ & 0.20 \\
\hline \multirow[t]{2}{*}{ MOF } & Yes & $4(15.4)$ & $16(11.0)$ & \\
\hline & No & $20(80.8)$ & $131(89.0)$ & 0.48 \\
\hline \multirow[t]{2}{*}{ Death } & Yes & $4(16.7)$ & $21(14.3)$ & \\
\hline & No & $20(83.3)$ & $126(85.7)$ & 0.75 \\
\hline
\end{tabular}

Abbreviations: ITU, intensive treatment unit; MOF, multiorgan failure; SD, standard deviation; TEDS, Treatment Episode Data Set; VTE, venous thromboembolism.

Note: Results are reported as mean and standard deviation (SD) or median (range) or number with \% as appropriate.

$p$-Values in bold indicate that the difference between the patients with thrombosis vs no thrombosis is significant. 
were no differences in the age, sex, and body mass index (BMI) between patients with or without thrombosis. No differences were observed in complete blood cell count, fibrinogen, or activated partial thromboplastin time, or $\mathrm{PaO} 2 / \mathrm{FiO} 2$ ratio (Supplementary Table S1) between groups at presentation. A trend toward higher D-dimer levels was noted in patients who developed thrombosis (median [range] 2,500 ng/mL [500-> 20,000] vs. 2,300 [450-19,730], $p=0.08)$. However, mean platelet volume (MPV) (reference range 7.4-11.5 fL) and prothrombin time values (reference range 12.2-17.4 seconds) were significantly higher in thrombosis patients at presentation (11.8 [range 7.4-12.9] vs. 10.1 [range 7.3-11.6] fL, $p=0.01$ and 19.3 [range 12.8-24.7] vs. 17.3 [range 12.1-20.1] seconds, $p=0.04$, respectively). Presence of renal or hepatic dysfunction and requirement for renal replacement were significantly higher in patients who developed thrombosis. As previously reported, ${ }^{9}$ patients treated in intensive therapy unit (ITU) had significantly higher rate of thrombosis (10/29, 34.5\%), than those treated in general medical wards (14/142, 9.8\%), $p=0.001$.

Although weight-, D-dimer-, and renal function-adjusted thromboprophylaxis was recommended, only 110/171 patients were treated according to the guidelines, while all others $(61 / 171)$ received standard LMWH thromboprophylaxis. The reason for nonadherence was not documented and was most likely attributable to the lack of awareness of recently introduced guidelines. In univariate analysis, no differences were found in age, sex, and laboratory tests (including D-dimer or C-reactive protein) or $\mathrm{PaO} 2 / \mathrm{FiO} 2$ ratio at presentation between patients who received intensified versus standard dose of LWMH ( - Table 3). Therefore, multivariate analysis was not performed.

Table 3 Comparison of demographic and clinical features and outcomes of patients received who intensified regimen versus standard regimen of $\mathrm{LMWH}$

\begin{tabular}{|c|c|c|c|c|}
\hline Variable & Category & $\begin{array}{l}\text { Intensified regimen, } \\
\text { mean (SD)/N (\%) } \\
110 / 171(\%)\end{array}$ & $\begin{array}{l}\text { Standard regimen, } \\
\text { mean (SD)/N (\%) } \\
61 / 171(\%)\end{array}$ & $p$-Value \\
\hline Age (y) (mean [SD]) & & $64.40(13.7)$ & $65.3(16.0)$ & 0.61 \\
\hline \multirow[t]{2}{*}{ Gender } & Male & 67 (60.9) & 35 (57.4) & \\
\hline & Female & $43(39.1)$ & $26(42.6)$ & 0.74 \\
\hline $\begin{array}{l}\text { Body mass index }\left(\mathrm{kg} / \mathrm{m}^{2}\right) \\
(\text { mean }[\mathrm{SD}])\end{array}$ & & $28.39(7.1)$ & $27.9(7.2)$ & 0.60 \\
\hline \multirow[t]{9}{*}{ Ethnicity } & Arab & $2(1.8)$ & $1(1.6)$ & \\
\hline & Asian/other Asian & $8(5.4)$ & $2(3.3)$ & \\
\hline & Black & $13(11.8)$ & $9(14.8)$ & \\
\hline & Chinese & $2(1.8)$ & $0(0.0)$ & \\
\hline & Indian & $7(6.4)$ & $5(8.2)$ & \\
\hline & Mixed & $2(1.8)$ & $0(0.0)$ & \\
\hline & Other & $20(18.2)$ & $17(27.9)$ & \\
\hline & White & $53(48.2)$ & $26(42.6)$ & \\
\hline & Unknown & $3(2.7)$ & $1(1.6)$ & 0.33 \\
\hline \multirow[t]{4}{*}{ Smoking } & Current & $11(10.0)$ & $4(6.6)$ & \\
\hline & No & 59 (53.6) & $28(45.9)$ & \\
\hline & Ex-smoker & $20(18.2)$ & $13(21.3)$ & \\
\hline & Unknown & $20(18.2)$ & $16(26.2)$ & 0.32 \\
\hline \multirow[t]{2}{*}{ Diabetes mellitus } & Yes & $32(29.1)$ & $23(37.7)$ & \\
\hline & No & $78(70.9)$ & $38(62.3)$ & 0.30 \\
\hline \multirow[t]{2}{*}{ Cardiac history } & Yes & $16(14.6)$ & $7(11.5)$ & \\
\hline & No & $94(85.5)$ & $54(88.5)$ & 0.64 \\
\hline \multirow{2}{*}{$\begin{array}{l}\text { Malignancy - Active or } \\
\text { treated in last } 6 \text { mo }\end{array}$} & Yes & $12(10.9)$ & $5(8.20)$ & \\
\hline & No & $98(89.1)$ & $56(91.8)$ & 0.79 \\
\hline \multirow[t]{2}{*}{ Autoimmune disease } & Yes & $8(12.5)$ & $6(9.8)$ & \\
\hline & No & $102(87.5)$ & $55(91.2)$ & 0.57 \\
\hline \multirow[t]{2}{*}{ Family history of VTE } & Yes & $14(12.7)$ & $7(11.5)$ & \\
\hline & No & $96(87.3)$ & $54(88.5)$ & 1.00 \\
\hline
\end{tabular}


Table 3 (Continued)

\begin{tabular}{|c|c|c|c|c|}
\hline Variable & Category & $\begin{array}{l}\text { Intensified regimen, } \\
\text { mean (SD)/N (\%) } \\
110 / 171(\%)\end{array}$ & $\begin{array}{l}\text { Standard regimen, } \\
\text { mean (SD)/N (\%) } \\
61 / 171(\%)\end{array}$ & $p$-Value \\
\hline \multirow{2}{*}{$\begin{array}{l}\text { Presence of renal or } \\
\text { hepatic dysfunction }\end{array}$} & Yes & $7(6.4)$ & $3(4.9)$ & \\
\hline & No & $103(93.6)$ & $58(95.1)$ & 1.00 \\
\hline \multirow[t]{2}{*}{ Renal replacement therapy } & Yes & $6(5.5)$ & $4(6.6)$ & \\
\hline & No & $104(94.6)$ & $57(93.4)$ & 0.74 \\
\hline \multirow[t]{2}{*}{ ITU admission } & Yes & $13(11.8)$ & $16(28.1)$ & \\
\hline & No & $97(88.2)$ & 41 (71.9) & 0.016 \\
\hline \multirow[t]{2}{*}{ Major bleeding } & Yes & $8(7.3)$ & $3(5.0)$ & \\
\hline & No & $102(92.7)$ & $57(95.0)$ & 0.74 \\
\hline \multirow[t]{2}{*}{ Minor bleeding } & Yes & $15(13.6)$ & $6(9.8)$ & \\
\hline & No & $95(86.4)$ & $55(90.6)$ & 0.62 \\
\hline \multirow[t]{2}{*}{ MOF } & Yes & $9(8.2)$ & $11(17.7)$ & \\
\hline & No & $101(91.8)$ & $50(82.3)$ & 0.082 \\
\hline $\begin{array}{l}\text { Length of stay in hospital (me- } \\
\text { dian and range) } d\end{array}$ & & $8(4-36) d$ & $9(3-39) d$ & 0.51 \\
\hline \multirow[t]{2}{*}{ Thrombosis } & Yes & $9(8.2)$ & $15(24.6)$ & \\
\hline & No & $101(91.8)$ & $46(75.4)$ & 0.005 \\
\hline \multirow[t]{2}{*}{ Death } & Yes & $12(10.9)$ & $13(21.3)$ & \\
\hline & No & $98(89.1)$ & $51(78.7)$ & 0.074 \\
\hline
\end{tabular}

Abbreviations: ITU, intensive treatment unit; LMWH, low molecular weight heparin; MOF, multiorgan failure; SD, standard deviation; VTE, venous thromboembolism.

Note: Results are reported as mean and standard deviation (SD) or median (range) or number with \% as appropriate. $p$-Values in bold indicate that the difference between the two groups is significant.

As hypothesized, a significantly higher proportion of patients who received standard thromboprophylaxis had CTPA (43/61) compared with those who received intensified thromboprophylaxis (39/110), $p<0.0001$, but there was no difference in the proportion of patients with PE who had CTPA in the two groups $(8 / 39,20.5 \%$ vs. $13 / 43,30.2 \%), p=0.44$. This indicates a lack of bias resulting from physician knowledge of the thromboprophylaxis regimen. Those who received the recommended adjusted dose of LMWH had significantly lower rate of thrombosis $(9 / 110,8.2 \%)$ compared with those receiving standard thromboprophylaxis (15/61, 24.6\%), $p=0.005$. The number of patients admitted to ITU was significantly lower in patients receiving adjusted dose LMWH $(13 / 100,11.8 \%)$ compared with standard dose $(16 / 61,28.07 \%, p=0.01)$. Transfer to ITU was only after several days for both patients receiving intensified thromboprophylaxis (6 days [range 4-12]) and those receiving standard thromboprophylaxis ( 7 days [range 4-13]). These are not significantly different: $p=0.52$. Although the differences in multiorgan failure (MOF) and mortality between groups were not significant ( $p=0.08$ and 0.07 ), the trends were toward better outcomes with adjusted dose LMWH and may be limited by sample size ( - Table 3 ). Importantly, there were no differences in major or clinically significant nonmajor bleeding in patients with thrombosis versus no thrombosis or those receiving adjusted versus standard thromboprophylaxis.
In this retrospective single-center study, patients who received intensified LMWH dose based on weight, renal function, and D-dimer levels had significantly lower rate of thrombosis and admission to intensive care unit (ICU) compared with those who received standard thromboprophylaxis. There were no differences in the age, gender, BMI, or other preexisting comorbidities between the two groups, which are known to be associated with worse outcome in patients with COVID-19.

The incidence of thrombosis in patients with COVID-19 infection is not fully established and reports of incidence vary widely from 3 to $40 \%{ }^{7,9-11}$ Overall, the data indicate that the incidence is higher than in comparable patients, but the figures are likely confounded by differences in severity of infection in the studied groups (thrombosis being more common with increasing severity as observed here), by use and intensity of thromboprophylaxis regimens, by diagnostic criteria (not all studies required objective detection of thrombosis), inclusion of patients requiring extracorporeal membrane oxygenation, and by ethnic differences in thrombotic tendency. The thrombosis incidence of $34 \%$ in our patients on ITU is toward the higher end of the reported range (but lower than Middeldorp et al and Helms et al $)^{9,10}$ and the non-ITU patients' rate is similarly at the high end of the reported range. Notably, the rate of thrombosis and requirement for ITU admission were significantly lower in patients who received intensified and weight- 
adjusted thromboprophylaxis regimen, and there were trends toward lower rate of developing MOF and mortality, which could have reached significance if the sample size was larger.

The higher than expected rate of thrombosis despite standard thromboprophylaxis has prompted several other authors to adopt a policy of intensified thromboprophylaxis. ${ }^{10}$ An observational report of 2,773 patients hospitalized for COVID-19 showed a reduction in mortality in ICUs patients who received therapeutic anticoagulation. ${ }^{11}$ In patients needing mechanical ventilation $(N=395)$, in-hospital mortality was $29.1 \%$, with median survival of 21 days for those anticoagulated compared with $62.7 \%$ in patients who were not, with median survival of 9 days. Again, there was no significant increase in major bleeding ( $1.9 \%$ vs. $3 \% ; p=0.2)$. The impact of anticoagulation preceding admission is not clear and variable results have been reported. ${ }^{9,12,13}$

Apparent benefit from a D-dimer-, weight-, and renal function-adjusted thromboprophylaxis regimen may arise directly from more intense anticoagulation and prevention of large and small vessel thrombosis in patients with intense inflammatory reaction to the infection. High-intensity anticoagulation may also be of benefit because the high concentrations of acute phase reactants produce heparin resistance, with lower than expected anti-Xa levels achieved from standard dosing. ${ }^{14}$ In addition, obesity is associated with more severe disease, making weight-adjusted dosing regimen of particular benefit in this group of patients. Finally, noncoagulant effects of heparin on viral entry and potentiation of DNAase degradation of neutrophil extracellular traps may be beneficial. ${ }^{15}$

The association of impaired renal and hepatic function with thrombosis may reflect severity of disease. An increase in MPV suggests increased platelet turnover and shortened platelet survival may reflect sequestration in microvascular occlusions. The low frequency of thrombocytopenia may be because production is increased by the intense inflammatory response.

Like many current reports, the major limitations of this study are its relatively small sample size and retrospective design. While we believe these observational data are useful, there remains a need for randomized studies with selected and stratified treatment groups and several these studies are currently under way.

\section{Authors' Contributions}

D.R.J.A. was involved in study concept and design, analysis and interpretation of data, review of the literature, and prepared the first draft of the manuscript. C.S., D.S., P.K., E. M., N.B., C.G., and R.L. collected the data, E.K. and S.J.C. provided the radiology data and interpreted them, and $R$. A. analyzed the data. A.S. and M.L. interpreted the data, review of the literature, and revised the manuscript. All authors approved the final version of the manuscript.

\section{Funding \\ None}

\section{Conflict of Interest}

M.L. received consultancy fee from Shire, LFB, Roche, Sobi, Octapharma, Baxter, Bayer, Pfizer, CSL, and speaker bu- reau for Pfizer, Bayer, Roche-Chugai, Takeda, and Leopharma. The other authors state that they have no conflict of interest.

\section{Acknowledgments}

The authors would like to thank all clinical staff at adult intensive care units, hemostasis and thrombosis consultants on call, and radiology departments, Imperial College Healthcare NHS Trust.

\section{References}

1 Patel BV, Arachchillage DJ, Ridge CA, et al. Pulmonary angiopathy in severe COVID-19: physiologic, imaging, and hematologic observations. Am J Respir Crit Care Med 2020;202(05):690-699

2 Spyropoulos AC, Levy JH, Ageno W, et al; Subcommittee on Perioperative, Critical Care Thrombosis, Haemostasis of the Scientific, Standardization Committee of the International Society on Thrombosis and Haemostasis. Scientific and Standardization Committee communication: clinical guidance on the diagnosis, prevention, and treatment of venous thromboembolism in hospitalized patients with COVID-19. J Thromb Haemost 2020;18(08):1859-1865

3 Moores LK, Tritschler T, Brosnahan S, et al. Prevention, diagnosis, and treatment of VTE in patients with coronavirus disease 2019: CHEST guideline and expert panel report. Chest 2020;158(03): 1143-1163

4 Zhai Z, Li C, Chen Y, et al;Prevention Treatment of VTE Associated with COVID-19 Infection Consensus Statement Group. Prevention and treatment of venous thromboembolism associated with coronavirus disease 2019 infection: a consensus statement before guidelines. Thromb Haemost 2020;120(06):937-948

5 Zhou F, Yu T, Du R, et al. Clinical course and risk factors for mortality of adult inpatients with COVID-19 in Wuhan, China: a retrospective cohort study. Lancet 2020;395(10229):1054-1062

6 Poissy J, Goutay J, Caplan M, et al;Lille ICU Haemostasis COVID-19 Group. Pulmonary embolism in patients with COVID-19: awareness of an increased prevalence. Circulation 2020;142(02):184-186

7 Al-Samkari H, Karp Leaf RS, Dzik WH, et al. COVID-19 and coagulation: bleeding and thrombotic manifestations of SARSCoV-2 infection. Blood 2020;136(04):489-500

8 Du RH, Liang LR, Yang CQ et al. Predictors of mortality for patients with COVID-19 pneumonia caused by SARS-CoV-2: a prospective cohort study. Eur Respir J 2020;55(05):2000524

9 Middeldorp S, Coppens M, van Haaps TF, et al. Incidence of venous thromboembolism in hospitalized patients with COVID-19. J Thromb Haemost 2020;18(08):1995-2002

10 Helms J, Tacquard C, Severac F, et al;CRICS TRIGGERSEP Group (Clinical Research in Intensive Care and Sepsis Trial Group for Global Evaluation and Research in Sepsis) High risk of thrombosis in patients with severe SARS-CoV-2 infection: a multicenter prospective cohort study. Intensive Care Med 2020;46(06):1089-1098

11 Paranjpe I, Fuster V, Lala A, et al. Association of treatment dose anticoagulation with in-hospital survival among hospitalized patients with COVID-19. J Am Coll Cardiol 2020;76(01):122-124

12 Klok FA, Kruip MJHA, van der Meer NJM, et al. Incidence of thrombotic complications in critically ill ICU patients with COVID-19. Thromb Res 2020;191:145-147

13 Tremblay D, van Gerwen M, Alsen M, et al. Impact of anticoagulation prior to COVID-19 infection: a propensity scorematched cohort study. Blood 2020;136(01):144-147

14 Dutt T, Simcox D, Downey C, et al. Thromboprophylaxis in COVID19: anti-FXa-the missing factor? Am J Respir Crit Care Med 2020; 202(03):455-457

15 Leppkes M, Knopf J, Naschberger E, et al. Vascular occlusion by neutrophil extracellular traps in COVID-19. EBioMedicine 2020; 58:102925 